\title{
IMPROVING PHYSICS LEARNING OUTCOME THROUGH COOPERATIVE LEARNING MODEL OF GROUP INVESTIGATION TYPE AND STUDENT LEARNING MOTIVATION IN SMAN 1 PESANGGARAN-BANYUWANGI
}

\author{
Erni Wiyanti ${ }^{1}$ \\ Muhammad Firdaus ${ }^{2}$ \\ Hary Sulaksono ${ }^{3}$ \\ Higher Education of Economic Mandala \\ e-mail: erniwiyanti@ymail.com
}

\begin{abstract}
This research aims to determine the effect of GI type cooperative learning model and learning motivation, as well as the influence of interaction model of cooperative learning type GI and motivation to physics learning outcome. The population in this research is the students of class XI IPA SMAN 1 Pesanggaran-Banyuwangi, which consists of two classes of classes that are homogeneous, the control class and experimental class. The data used in this research are primary data collected from pre-test and post-test for learning outcome, and questionnaires for student motivation data. The instrument before it is tested has been tested for its validity and reliability. The statistical test uses two-way Anova analysis method with the help of SPSS computer program. The results showed that (1) there were significant differences between groups of students using cooperative type of GI learning model with conventional learning model on Physics learning Outcome. This conclusion is based on the result of two-way Anova analysis, the value (F Count) 13.491> (F table) 3,13 at significance level $(\alpha) 0,05$ and $\mathrm{P}$ value (Sig.) $0.000<(\alpha)$ 0,005. (2) there is a significant difference of influence between high motivated group of students with low motivation toward Physics learning Outcome This conclusion is based on the result of analysis of two path Anova analysis, that is value (F Count) 14,908 $<3,13$ (F table) on level Significance $(\alpha) 0.05$ and $\mathrm{P}$ value (Sig) $0.000<(\alpha) 0.05$. (3) There is no interaction of GI type cooperative learning model and learning motivation toward student physics learning result at SMAN 1 Pesanggaran. This conclusion is based on two-way Anova analysis test result (F Count) 0,036 <(F Table) 3,13 at significance level $(\alpha) 0,05$, and $\mathrm{P}$ value (Sig) $0,851<(\alpha) 0,05$. From the results of this research teachers are required to always innovate in choosing a model of learning. Due to selection of learning models in accordance with the conditions of learners and schools, it will be able to improve learning outcome. One of the learning models that can improve learning outcome is by using the GI model.
\end{abstract}

Keywords: Cooperative Type GI Learning Model, Learning Motivation, Learning Outcome.

\section{INTRODUCTION}

Education is a very important element to create quality human resources. Therefore education programs should always be reviewed and improved. School data from year to year shows relatively low learning outcomes. Possible cause is lack of innovation in learning. It drove the researchers to take the theme of the influence of learning model group investigation and student motivation on student outcome. 
Problems in this research are to what extent the influence of cooperative learning model of group investigation type on Physics learning outcome, to what extent the influence of students' learning motivation on Physics learning outcome and to what extent the interaction effect of cooperative learning model of group investigation type and motivation toward Physics learning Outcome, students' learning motivation, on students of SMAN 1 Pesanggaran-Banyuwangi

The purposes of conducting this research are to knowing the influence of cooperative learning model of group investigation type, students' learning motivation, and interaction model of cooperative learning of group investigation type and motivation toward Physics learning outcome in students of SMAN 1 Pesanggaran-Banyuwangi.

Limitations of the problem in this research is to compare the results of student learning using cooperative learning model of group investigation type with conventional model in XI IPA class (consist of 70 students) of SMAN 1 Pesanggaran-Banyuwangi. Another one is the influence of Physics learning motivation in improving learning Outcome.

In general, class organizing planning using Group Investigation cooperative technique is a group formed by the students themselves with 2 to 6 members. Each group is free to choose a subtopic of the entire unit of matter (subject) to be taught and then create or produce a group report. Subsequently, each group presents or exhibits its report to the entire class, to share and exchange information on their findings (Slavin, 2008).

Implementation of Group Investigation's cooperative learning strategy in learning is generally divided into 6 (six) steps: (1) Identifying topics and organizing students into groups (students review information sources, selecting topics, facilitating teachers in obtaining information), (2) Grouping, (3)
Conducting investigations (students seeking information, analyzing data, and making conclusions), (4) Preparing the final report, (5) Presenting the final report (presentations are made for the whole class in various forms), (6) Evaluating (teachers and students collaborate in evaluating learning, assessments directed to evaluate conceptual understanding and critical thinking skills).

In a large Indonesian dictionary (1991: 523), conventional means based on custom or traditional. Thus, conventional learning is the usual teaching done by the teacher. In general, conventional learning is a more teacher-centered learning.

In general, conventional learning which is done by educators so far has many weaknesses, such as: (1) Learning activities are merely transferring knowledge from teacher to students, (2) Learning activities look like to fill empty bottles with knowledge, (3) Conventional learning tends to separate things (4) Teaching activities emphasize more on outcomes than processes, (5) Encouraging students in competitions like cock fight, students work hard to beat their classmates.

Motivation is the mental power that drives learning. The driving force comes from various sources. Students learn something because they are driven by mental strength in the form of desire, attention, will, or ideals. The mental strength can be low or high. Motivation is divided into 2 groups, namely: (1) Intrinsic motivation is the motivation in you yourself to do something for the sake of something itself (the purpose itself). For example, learners may learn to face the test because they are happy in the lesson being tested, (2) Extrinsic motivation is doing something to get something else. Extrinsic motivation is often influenced by external incentives such as rewards and punishments.

Learning outcome is an indicator of the absorption (intelligence) of students. Learning outcome is influenced by some 
factors, namely Internal factors, factors that can be classified in these internal factors such as intelligence, talent, interest, and motivation of each individual. External factors, factors that include external factors such as family circumstances, experiences, the environment, learning models and so on. The function of learning outcome, along with: (1) As an indicator of the quality and quantity of knowledge that has been mastered by students, (2) As the symbol of the fulfillment of desire to know, (3) As an information material in educational innovation, (4) And extern of an educational institution.

\section{RESEARCH METHODS}

The research was conducted at SMAN 1 Pesanggaran Banyuwangi in November 2016. This research used experimental method, with the design of pre test-post test control group design. The experiments were carried out in two classes, namely class A and class B, which were samples of treatment samples using cooperative type group investigation method and control samples using conventional method.

\begin{tabular}{|l|}
\hline $\mathrm{N}_{1}-\mathrm{X}-\mathrm{N}_{2}$ \\
\hline $\mathrm{N}_{3}-\mathrm{N}_{4}$ \\
\hline
\end{tabular}

Information :

$$
\begin{aligned}
-\mathrm{X}-= & \text { Experiment Class } \\
\mathrm{N}_{1}= & \text { Control Class } \\
= & \text { Student learning outcome } \\
& \text { before getting cooperative } \\
& \text { learning model of group } \\
& \text { investigation type in } \\
& \text { experiment class. } \\
= & \text { Student learning outcome } \\
& \text { after getting cooperative } \\
& \text { learning model of group } \\
& \text { investigation type in } \\
& \text { experimental class. } \\
= & \text { Student learning outcome } \\
& \text { before getting }
\end{aligned}
$$

$$
\mathrm{N}_{4}=\begin{aligned}
& \text { conventional learning } \\
& \text { model in control class. }
\end{aligned}
$$

The population of this study involved students at XI IPA class of SMAN 1 Pesanggaran-Banyuwangi as many as 70 students, consisting of two (2) classes, namely XI IPA4 class amounted to 35 and XI IPA5 class amounted to 35. Sampling technique in this research is by purposive sampling. Sampling techniques based on certain considerations and characteristics.

Based on its type, this research includes Quasi Experimental research and survey research. Quasi Experimental Research is a research using experimental and control group treated by using pre testpost test group design as a data collection tool. While the survey research is a research that uses a questionnaire as a means of data collection (Sugiyono, 2012).

Variables of research is anything in the form of what is determined by the researcher to be studied, so obtained information about it, to then be drawn conclusion (Sugiyono, 2007). Independent variabels are Learning model (Cooperative Type Investigation and Conventional Group) and Learning Motivation (High and Low motivation). And Learning Outcome as Dependent Variables

In order to avoid misunderstanding with the terms used in this research, the authors describe the terms used in this research. Cooperative learning model of group investigation type is classroom organizing planning where group is made by students with 2 - 6 members, each group is free to choose subtopic of the entire unit of matter (subject) that will be taught, and make group report. Furthermore, each group presented its report to the whole class, to share and exchange information on their findings (Slavin, 2008) 
The conventional learning model (lecture) is the way the teacher conveys the teaching materials with a direct oral explanation of the students. This method makes more active teacher but less for students. They only listen and give answers when they asked to. Consequently, teacher who is less interesting in delivering lesson will make the students show less attention and sometimes sleepy (Suryobroto, 2009).

Motivation to learn is one that encourages students to learn which includes internal and external encouragement (Santrock, 2004). Learning Outcome is the result that has been achieved by students after the learning that in this research the focus is on the cognitive aspect only (Saeffudin Azwar, 2000).

Physics subject in question is a curriculum or syllabus of high school level on physics subject matter at XI IPA class. The material used in this research is about Work and Energy. Data collection methods are techniques or methods used to collect data. Data collection techniques used to conduct this research are test of learning outcome and motivation test of learning.

To obtain data in the form of Physics outcome, researchers used research instruments in the form of a test of ability (Outcome test) consisting of 20 items made by the researcher by taking the questions on Erlangga textbook. Therefore, the test of learning outcome does not need to be tested for the validity and reliability.

Data in the form of learning motivation is obtained by using questionnaire consisting of 25 items that support and not support the statement of problem. From the 25 items of the questionnaire, it was tested in another class before it was used in the experimental class and control class. After that it was tested for the validity and reliability. Each item has 5 choices. There are some research instruments to be used in research. Before being used, it should be tested first for quality. To test the quality of the instrument, it is used 2 kinds of test, namely validity and reliability test for outcome test and motivation.

\section{Validity test}

In this research the validity of instrument test is calculated by using product moment formula (Sugiyono, 2012: 183), as follows:

$$
r_{x y}=\frac{N \sum X i Y i-\left(\sum X i\right)\left(\sum Y i\right)}{\sqrt{\left\{N \sum X i^{2}-\left(\sum X i\right)^{2}\right\}} \sqrt{\left\{N \sum Y i^{2}-\left(\sum Y i\right)^{2}\right\}}}
$$

Information:

$\mathrm{R}_{\mathrm{xy}}=$ Product moment correlation coefficient between $\mathrm{x}$ and $\mathrm{y}$

$\mathrm{X}=$ Value of variable $\mathrm{X}$

$\mathrm{Y} \quad=$ The value of variable $\mathrm{Y}$

$\mathrm{N} \quad=$ Number of subjects

$\Sigma \quad=$ Sigma Number of values

\section{Test Reliability}

Reliability is a measure that shows reliable results if the test is tested multiple times (Sugiyono, 2012: 131). To know the reliability of the instrument by using Spearman Brown, the formula is as follows:

$$
\left\lceil r_{i}=\frac{2 r_{s}}{1+r_{s}}\right\rceil
$$

Information:

$$
\begin{aligned}
\mathrm{R}_{\mathrm{i}}= & \text { the overall correlation } \\
\mathrm{Rs}= & \begin{array}{l}
\text { coefficient of the question } \\
\text { half-problem correlation } \\
\text { coefficient found to know the } \\
\text { correlation level can use dallar } \\
\text { as follows. }
\end{array}
\end{aligned}
$$

1. $0.80<\mathrm{r}_{\mathrm{i}}, 1,00$ correlation is very high

2. $0.60<\mathrm{ri}, 0,79$ high correlation

3. $0.40<\mathrm{ri}, 0,59$ moderate correlation

4. $0.20<\mathrm{ri}, 0,39$ low correlation

5. $0.00<\mathrm{r}_{\mathrm{i}}, 0,19$ correlation is very low

\section{Test Prerequisites}

The collected data need the processing and analysis because a research does not 
only rely on the rough data obtained from the results of the course, but also needs to be processed so that the data is easier to understand, read and interpreted.

Analytical techniques used to examine the use of cooperative learning model type of group investigation and motivation on student outcome in the classroom are by using Normality test and Homogeneity test.

a. Normality Test

Normality test conducted to determine whether the population is normally distributed (Sugiyono, 2012: 172). Normality test is using Kolmogorov Smirnov formula:

$$
D_{n}=\sum\left|F_{n(x)}-F_{(X)}\right|
$$

Information:

Dn : Kolmogorov significance value Fn (x) : Normal cumulative probability $\mathrm{F}(\mathrm{x})$ : The empirical cumulative probability

b. Homogeneity Test

Homogeneity test is intended to determine whether the population has the same variant or not (Sugiyono, 2012: 197). In this case, it is used Homogeneity test of variance with the following formula:

$$
F=\frac{\text { Largest Variant }\left(s^{2}\right)}{\text { Smallest Variant }\left(s^{2}\right)}
$$

Information:

$\mathrm{F}: \mathrm{F}$ test count value The largest variant (s2): The largest variant value The smallest variant (s2): The smallest variant value
If $\mathrm{F}_{\text {Count }}>\mathrm{F}_{\text {table, }}$, means population used homogeny, and vice versa, if $\mathrm{F}_{\text {Count }}>$ $\mathrm{F}_{\text {table, mean population used is not }}$ homogeneous.

To calculate the value of variant used the following formula: (Sugiyono, 2012: 183)

$$
s^{2}=\sqrt{\frac{n \cdot \sum X^{2}-\left(\sum X\right)^{2}}{n(n-1)}}
$$

Information:

$\mathrm{N}=$ Number of samples

$\mathrm{X}=$ Value obtained by sample

$\mathrm{X}^{2}=$ Squares of the values obtained by the sample

\section{Hypothesis Testing}

Hypothesis test is done to find out whether the hypothesis in the research accepted or rejected (Sugiyono, 2012: 192). In this research hypothesis test is using analysis of variance (using a twoway anova) as follows:

$$
F_{h}=\frac{R^{2} / k}{\left(1-R^{2}\right) /(n-k-1)}
$$

Information:

Fh : Coefficient of double correlation

$\mathrm{k} \quad$ : Number of independent variables

n : Number of sample members

The data obtained were then tabulated using a 2x2 factorial design and analyzed by using $\mathrm{F}$ test statistic (using a two-way anova)

Table Factorial Design 2 x 2

\begin{tabular}{|c|c|c|}
\hline & \multicolumn{2}{|c|}{ METHOD } \\
\cline { 2 - 3 } & $\begin{array}{c}\text { Co-operative Type Group } \\
\text { investigation (A1) }\end{array}$ & $\begin{array}{c}\text { Conventional } \\
\text { (A2) }\end{array}$ \\
\hline MOTIVATION & A1.B1 & A2.B1 \\
\hline LOW (B2) & A1.B2 & A2.B2 \\
\hline
\end{tabular}


Information:

A1.B1 : Sel group of students who are given cooperative learning type group investigation and have high learning motivation.

A2.B1 : Sel group of students who are given conventional learning and have high motivation.

A1.B2 : Sel group of students who are given cooperative learning type group investigation and have low learning motivation.

A2.B2 : Sel group of students who are given conventional learning and have low motivation.

After analyzing statistical data with Microsoft Exel and SPSS as above step, then it consulted with $\mathrm{F}$ test distribution table (attached), so that it can be taken conclusion as follows:

a. If the results of statistical analysis with

Microsoft Exel and SPSS obtained results $\mathrm{F}_{\text {Count }}<\mathrm{F}_{\text {table, }}$ then $\mathrm{H}_{\mathrm{o}}$ is rejected and $\mathrm{H}_{1}$ accepted.

b. Vice versa, if from the results of statistical analysis with Microsoft Exel and SPSS obtained $F_{\text {count }}>F_{\text {table, }}$, then $\mathrm{H}_{\mathrm{o}}$ accepted and $\mathrm{H}_{1}$ rejected.

\section{RESULT ANALYSIS}

Respondents were students of class XI IPA 4 and IPA 5 SMAN 1 Pesanggaran which amounted to 70 students, and divided into 2 classes namely experimental class and control class.

Data on the influence of cooperative learning model of Group Investigation and learning motivation toward Physics learning Outcome in SMAN 1 Pesanggaran-Banyuwangi as a whole as in the table below.

Table Summary of Research Data Influence of Cooperative Learning Model of GI Type And Motivation To Learning Outcome

\begin{tabular}{c|c|c|c}
\hline Model Motivation & High & Low & Total \\
\hline Co-operative type GI & 27 & 8 & 35 \\
$\mathrm{~N}$ & 81,85 & 74,38 & 80,14 \\
Mean & 9,109 & 4,955 & 8,869 \\
Sd & 2210 & 595 & 2805 \\
$\sum \mathrm{X}$ & 18 & & 35 \\
Conventional & 74,72 & 67,94 & 71,43 \\
$\mathrm{~N}$ & 6,057 & 4,351 & 6,251 \\
Mean & 1345 & 1155 & 2500 \\
Sd & & & \\
$\sum \mathrm{X}$ & 45 & 25 & 70 \\
$\mathrm{~N}$ & 79 & 70 & \\
Mean & 8.7 & 5,401 & \\
Sd & 3555 & 1750 & \\
$\sum \mathrm{X}$ & &
\end{tabular}

From table above, it shows that:

a. There is a significant difference between groups of students who are learning with a GI type cooperative model with those using conventional learning model in Physics learning outcome is shown by mean value in learning pretation that result from cooperative learning model type GI 80,14 and with conventional learning model 71, 43.

b. There is a significant difference between high motivated and low motivated students in Physics learning 
outcome as indicated by mean niali on highly motivated learning pretensions 79 and low motivation 70 .

c. There is no significant effect of interaction between Group Investigation cooperative learning model with motivation to Physics outcome which is indicated by mean value in cooperative group type GI with low motivation 74,38 and conventional group with low motivation 67,94 .
Hypothesis testing is done by two-way vaktorial analysis. The goal is to investigate the two main effects namely the difference of application of learning models and student learning motivation to Physics learning outcome. And the influence of interaction (interaction effect) affected both on Physics learning outcomes. A summary of the results of two-way vaktorial analysis is included in the table below.

Table Analysis of Anova Two Path Analysis Tests of Between-Subjects Effects

\begin{tabular}{l|c|c|c|c|c}
\hline \multicolumn{6}{c}{ Tests of Between-Subjects Effects } \\
\hline \multicolumn{1}{c}{ Source } & $\begin{array}{c}\text { Type III Sum of } \\
\text { Squares }\end{array}$ & df & Mean Square & F & Sig. \\
\hline Corrected Model & $2075.951^{\mathrm{a}}$ & 3 & 691.984 & 14.027 & .000 \\
Intercept & 323191.648 & 1 & 323191.648 & $6.552 \mathrm{E} 3$ & .000 \\
Model_Learn & 665.545 & 1 & 665.545 & 13.491 & .000 \\
Motivation_to learn & 735.441 & 1 & 735.441 & 14.908 & .000 \\
Model_Belajar* & 1.752 & 1 & 1.752 & .036 & .851 \\
Motivation_Learn & 3255.835 & 66 & 49.331 & & \\
Error & 407375.000 & 70 & & & \\
\multicolumn{1}{c}{ Total } & 5331.786 & 69 & & & \\
\hline
\end{tabular}

a. R Squared $=.389($ Adjusted R Squared $=.362)$

Based on the $t$ test steps and the above table, the hypothesis testing for each independent variable are as follows: There are differences in learning outcomes of students who were taught using conventional learning models with students taught by cooperative learning model GI. This conclusion is based on analysis of test results of Anova two ways in table 4.9 above, the value of $\left(F_{\text {Count }}\right) 13$ 491> $(\mathrm{F}$ table) 3,13 at significance level $(\alpha)$ of 0.05 and a $\mathrm{P}$ value (Sig.) $0000<(\alpha)$ 0.005. This means $\mathrm{H}_{0}$ is rejected and $\mathrm{H}_{1}$ accepted.

There are differences in student learning outcomes that have high learning motivation when compared with students who have low learning motivation. This conclusion is based on analysis of test results of Anova two ways in table 4.9 above, the value of ( $\mathrm{F}$ count $) 14,908<3.13$ $\left(F_{\text {table}}\right)$ at significance level $(\alpha)$ of 0.05 and a $\mathrm{P}$ value (Sig) $0.000<(\alpha)$ 0.05. This means $\mathrm{H} 1$ is accepted and $\mathrm{H} 0$ is rejected.

There is no interaction of GI type cooperative learning model and learning motivation to student Physics learning result at SMAN 1 Pesanggaran. This conclusion is based on analysis of test results of Anova two ways in table 4.9 above, the value of ( $\left.F_{\text {count }}\right) 0.036<\left(F_{\text {table }}\right)$ 3,13 at significance level $(\alpha)$ of 0.05 , and a $\mathrm{P}$ value (Sig) $0.851<(\alpha) 0.05$. This means that $\mathrm{H} 0$ is accepted and $\mathrm{H} 1$ is rejected. 


\section{INTERPRETATION}

From the observation and analysis above, it is found that there is an increasing number of students who reach KKM (Minimum Limit Criteria) that is equal to 75 . From 35 students of experimental class, $77.14 \%$ of students who scored above KKM, and students who got a value below the KKM only $22.86 \%$. Meanwhile in the control class, from 35 students, it found that $37.14 \%$ of students who scored above the KKM, and students who scored under the KKM $62.86 \%$. This means that the application of the learning model contributes greatly to student learning outcomes. It means that the current research could reinforce the results of previous studies, especially research that was conducted by Kustiani (2013) and Artini (2015).

Post-test results in high motivated students and low motivated students are better on high motivated students. In the highly motivated students of 45 students, the mean (average score) of the post-test was 79. Whereas in the low motivated students of 25 students, the mean (average score) of the post-test was 70. It indicates that the high motivation to learn the students will be able to improve student learning outcomes. It means this research can strengthen the results of research conducted by Astiti (2012) and Supriyadi (2013). Consequently, it rejects the results of research conducted by Siswati (2014).

The results showed that there was no significant influence between the interactions of cooperative learning model of group investigation type with motivation to Physics learning outcome. This is shown from the statistical test with the help of computer program SPSS, obtained F Count (0.036) $<$ F table (3.13), Sig value. 0.851>0.05. This can occur because of other influences such as the condition of students who studied at the time and also the accuracy of the data is less because when the data collection students are in one room that can provide opportunities for students to cooperate in working on learning Outcomes andsoal questionnaire. From the results of this research found that the interaction between cooperative learning model and student learning motivation does not affect student Outcome. It means this research can strengthen the result of research done by Siswati (2014) and reject the result of research conducted by Supriyadi (2013). Therefore it is expected for the next researcher to further improve the accuracy in taking data on the sample research.

\section{CONCLUSION}

Based on the research objectives, the results of research and data analysis in the previous chapter can be summarized as follows:

6. There is a significant influence between groups of students who are learning by using cooperative learning model of Group Investigation type with students using conventional learning model in improving learning outcome in Physics subject matter of Energy and Work.

7. There is a significant influence between groups of students who have high motivation and who have low motivation in improving learning outcome in Physics subject matter of Work and Energy.

8. There is no significant influence between the interaction of the use of model research Group Investigation type with students' learning motivation to improve learning outcome in Physics subject matter of Energy and Work.

\section{IMPLICATIONS}

Based on the above conclusions, it can be stated that the learning media has the characteristics and role of each in determining the success of teaching and learning process. This suggests that all other learning objectives of the diversity of 
instructional media require a teacher to selectively select media that is appropriate to the learning objectives. An educator must be able to select and sort out the learning model that can encourage the improvement of learning outcomes for the students, one of them with cooperative learning model of Investigation Group type. By applying the model of learning GI, students will tend to be active and creative in the learning process. It is significant because in this learning model there are Pre-Test activities at the beginning of learning activities, this will require students to try to find their own information from existing learning resources, with the intention that the value is good. While in other cooperative learning model there is no Pre-Test activity at the beginning of learning activities.

The Group Investigation cooperative learning model provides an opportunity to learn not only from one learning resource such as a teacher, but also provides an opportunity for the subject to develop cognition better, creative and innovative. It happens because in this learning model learners are required to find out their own information about a material, and the results should be presented using an ITbased learning media (computer).

\section{REFERENCES}

Arikunto. 2002. Metode Penelitian Kuantitatif dan $R \quad \& \quad D$. Bumi Aksara: Jakarta.

Arikunto. Suharsimi. 2006. Prosedur Penelitian.Jakarta: Rineka Cipta.

Artini (2015) tentang Penerapan Model Pembelajaran Kooperatif Tipe Group Investigation Untuk Meningkatkan Aktivitas dan Hasil Belajar IPA Pada Siswa Kelas VI SD Inpres 1 Tondo. Jurnal Penelitian Magister Pendidikan Sains Pascasarjana Universitas Tadulako http://jurnal.untad.ac.id/jurnal/
index.php/MitraSains/article/view/4135 13075. Diakses pada 16/09/2016.

Astiti. 2012. Pengaruh Model Pembelajarn Kooperatif Tipe STAD dan Motivasi Outcome Terhadap Hasil Belajar IPS Siswa Kelas VII SMP Negeri 2 Semarapura-

Singaraja.Pascasarjana-Undiksa-

Bali. http://pasca.undiksha.ac.id/ejournal/index.php/jurnal_ep/article/vie w/31. Diakses pada 16/09/2016

Azwar, Saeffudin. 2000. Penyusunan Skala Psikologi. Yogyakarta. Pustaka Pelajar

Burhanudin, S. 2006. Model Pembelajaran Group Investigasi. Available : www.geocities.com. Diakses pada 16/09/2016.

Departemen Pendidikan dan Kebudayaan. 1990. Kamus Besar Bahasa Indonesia. Jakarta. Balai Pustaka.

Departemen Pendidikan dan Kebudayaan. 2003. Model-model Pembelajaran Dirjen Pendidikan Dasar dan Menengah Departemen Pendidikan Nasional. Jakarta. PGSM.

Ibrahim. 2000. Pembelajaran Kooperatif. Surabaya. Universitas Negeri Surabaya.

Kushendar, Denny Mahendra. 2010. Pengertian Outcome Belajar. Jurnal Hasil Riset.

Kustiani. 2013. Implementasi Model Pembelajaran Kooperatif Tipe Group Investigation dalam Meningkatkan Hasil Belajar Matematika Siswa Kelas V SD 1 Jurang Kabupaten Kudus. Jurnal Penelitian Universitas Muria-Kudus. Diakses pada 16/09/2016.

Lie, A. 2002. Cooperative Learning. Jakarta. Penerbit Grasindo.

Ridwan. 2006. Skala Pengukuran Variabel-variabel Penelitian. Bandung. Alphabeta.

Santoso, Purbayu Budi. 2005. Analisa Statistik dengan Microsoft Exel dan SPSS. Yogyakarta. Andi. 
Santrock, J W. 2004. Educational Pshycology, New York, Mc GrawHill.

Sardiman, A.M. 2011 Interaksi dan Motivasi Belajar Mengajar, Jakarta. Raja Grafindo Persada.

Slavin, Robert,E. 2008. Cooperative Learning Teori, Riset dan Praktik. Bandung. Nusa Media.

Suciati, Prasetya Irawan. 2001. Teori Belajar dan Motivasi, Jakarta. PAUPPAI Universitas Terbuka.

Sugiyono. 2012 Metode Penelitian Kuantitatif, Kualitatif dan $R \& D$. Bandung. Alfabeta

Suryobroto. 2009.Metode Pembelajaran Konvensional. JurnalKompasiana.com. www.kompasiana.com/m.anasjurnalartikel. Diakses pada 16/09/2016.

Sutama. 2007. "Model Pembelajaran Kooperatif Tipe Group Investigation untuk Mengembangkan Kreatifitas Mahasiswa". Varidika. 19 (1): 1-14. Jurnal.

pdii.lipi.go.id/admin/jurnal/1910711 4.pdf.

Trihendradi, C. 2012. SPSS 20 Step By Step Analisis Data Statistik. Yogyakarta. Penerbit ANDI.

Tsay, Mina and Brady, Miranda. 2010 "A case research of cooperative learning and communication pedagogy" in Journal of the scholarship of Teaching and Learning. Vol 10, No 2. Available at <http:/www.iupul.edu/josotl>

Warpala, IWS.2011. Melaksanakan Tindak Pembelajaran Bermakna: Merajut Inovasi dan Menuai Prestasi, Makalah disampaikan pada penataran Guru muda pola 90jam Undiksha. Singaraja.

\section{BIOGRAPHY}

Erni Wiyanti was born in Banyuwangi, May 24, 1979. She is the seventh child of 7 siblings from the couple (Alm.) Bpk. Tamin and (Alm.) Ibu Tijah. The author is Muslim and lives at Dusun Tembakur RT. 04 RW II Sumbermulyo Village, Pesanggaran Sub-district, Banyuwangi. education experience are as follows: SDN 2 Bangorejo-Banyuwangi, SMPN 1 Bangorejo-Banyuwangi, SMAN 1 Genteng-Banyuwangi, S1 Physics Education UNEJJember, Masters Degree in Management STIE Mandala Jember. work experience are as follows: teacher at SMAN 1 Pesanggaran-Banyuwangi, teacher at STM Muhammadiyah Pesanggaran-Banyuwangi and Civil servant teacher at SMAN 1 Pesanggaran-Banyuwangi 